\title{
CELIAC DISEASE IN BRAZILIAN PATIENTS: associations, complications and causes of death. Forty years of clinical experience
}

\author{
Lorete Maria da Silva KOTZE*
}

\begin{abstract}
Context - Celiac disease is a multisystem auto-immune disorder and may start at any age in genetically predisposed individuals. Objective - To identify associations, complications, and cause of death in Brazilian patients. Methods - One hundred and fifty-seven patients were studied: 23 adolescents and 134 adults, $79.6 \%$ females, $20.4 \%$ males, $75.8 \%$ at the time of diagnosis and $24.2 \%$ on a gluten-free diet, follow-up between 1 and 40 years. The diagnosis of celiac disease was based on histologic findings and the presence of serologic auto-antibodies markers for celiac disease. Specific tests were done according to clinical suspicion of associations. Bone mineral density was determined by dual energy x-rays in 53 patients upon diagnosis. The data regarding associations, complications, and causes of death were obtained by interviews and from the patient's charts. - Results - Associations: atopy (22.3\%), depression (17.2\%), thyroid disorder (15.9\%), dermatitis herpetiformis (11.5\%), diabetes mellitus types 1 and $2(4.5 \%)$ and tumors (4.5\%). Complications - Anemia and osteopenia/osteoporosis in all groups; increased number of spontaneous abortion. Four patients $(4.5 \%)$ died (one from lymphoma, one with diabetes type 1, one from acute meningitis and one due to suicide). Conclusions - This experience is similar to those described in the world literature. Celiac disease presents the same characteristics independently of the geographic region. We recommend periodic evaluations, from childhood, independent of the duration of the diet. The key is to establish an interval between evaluations.
\end{abstract}

HEADINGS - Celiac disease. Gluten. Lymphoma, non-Hodgkin.

\section{INTRODUCTION}

Celiac disease (CD) is a small intestine disorder caused by adaptive and innate immune responses triggered by gluten proteins present in wheat, barley, rye and oats ${ }^{(2,}$ ${ }_{10,36}$. CD is far more common than previously thought and may start at any age. The disease may present a wide clinical spectrum, from malabsorption syndrome to extra-intestinal presentations, and can be atypical or asymptomatic ${ }^{(25,74)}$. Serologic tests are useful for screening and histological abnormalities confirm the diagnosis $^{(38,74)}$. CD is associated with autoimmune disorders and can cause complications and death.

The aim of the study was to identify associated diseases, complications and causes of death of Brazilian patients with CD.

\section{METHODS}

\section{Patients}

One hundred fifty-seven celiac patients were studied retrospectively, 125 females $(79.6 \%)$ and 32 males $(20.4 \%), 119(75.2 \%)$ at diagnosis and $38(24.2 \%)$ on a gluten-free diet (GFD), follow-up of between 1 to 40 years. Informed consent was obtained from participants, and the study was approved by the Ethic Committee of the institution. The groups were divided as follows:

Group I - adolescents $(\mathrm{n}=23 ; 14.6 \%): 11$ to 20 years, mean age $=16.3$ years; 14 female and 9 male, 5 at diagnosis and 18 on a gluten-free diet.

Group II - young adults ( $\mathrm{n}=71 ; 45.2 \%): 21$ to 40 years, mean age $=29.8$ years; 60 female and 11 male; 59 at diagnosis and 12 on a gluten-free diet

Group III - adults $(\mathrm{n}=52 ; 33.1 \%): 41$ to 60 years, mean age $=48.2$ years; 45 female and 7 male; 40 at diagnosis and 5 on a gluten-free diet

Group IV - elders $(\mathrm{n}=11 ; 7.0 \%)$ : 61 to 80 years, mean age $=66.4$ years; 6 female and 5 male; 10 at diagnosis and 1 on a gluten-free diet

At diagnosis, bone diseases were studied in 53 patients: 4 male $(7.5 \%)$ and 49 female $(92.5 \%), 16$ $(32.6 \%)$ were post-menopausal. The patients on a GFD were not included in this part of the research.

\section{METHODS}

The diagnosis of $\mathrm{CD}$ was based on clinical evaluation, on histological findings $\mathrm{s}^{(39)}$ and on the presence of serologic auto-antibodies: $\operatorname{IgA}$ antiendomysium $(\operatorname{IgA~EmA})^{(70)}$

*Gastroenterology Service, Cajuru Hospital, Pontifical Catholic University of Paraná, Curitiba, PR, Brazi

Correspondence: Dr. Lorete Maria da Silva Kotze - Rua Bruno Filgueira, 369 - Cj. 1205 - 80240-220 - Curitiba, PR, Brazil. E-mail: loretekotze@hotmail.com 
and $\operatorname{IgA}$ anti-tissue transglutaminase (IgA anti-tTG) $)^{(20,24)}$. Prior determination of IgA levels was made by turbidimetry.

All patients were submitted to routine blood tests and specific tests according to the clinical suspicion of associated disorders. Psychiatric disturbances were diagnosed according to DSM IV.

Bone mineral density (BMD) of the spinal cord and femoral neck were determined by dual energy x-ray absorptiometry $(\text { DEXA) })^{(17)}$.

The data concerning associated diseases and complication were obtained from interviews and from the patients' charts, based in a standard protocol. The causes of death were checked from death certificates. Common diseases for each group were not recorded in the study, only disorders referred to in the literature as $C D$ related.
Statistical analysis was performed using the Fisher's exact test with Bonferroni correction, significance level $P<0.008$.

\section{RESULTS}

The associated disorders were detected before, during or after the diagnosis of $\mathrm{CD}$, independent of age at diagnosis or the duration of the diet (Table 1). Comparison between the groups showed statistical significance for depression and thyroid disease for the adults $(P<0.001)$ (Table 2). Several patients presented more than one association (Table 3 ), increasing the number with age (adults) (Table 4).

Anemia, at diagnosis, was detected in all the groups: $65.2 \%$ in the adolescents, $76.5 \%$ in young adults, $73.9 \%$ in adults and $55.6 \%$ in the elders, without statistical significance.

TABLE 1. Principal associated disorders in the studied patients

\begin{tabular}{|c|c|c|c|c|c|}
\hline Associated diseases & $\begin{array}{l}\text { Group I } \\
\text { Adolescent } \\
(\mathrm{n}=23)\end{array}$ & $\begin{array}{l}\text { Group II } \\
\text { Young adult } \\
(\mathrm{n}=71)\end{array}$ & $\begin{array}{l}\text { Group III } \\
\text { Adult } \\
(\mathrm{n}=52)\end{array}$ & $\begin{array}{l}\text { Group IV } \\
\text { Elderly } \\
(\mathrm{n}=11)\end{array}$ & $\begin{array}{c}\text { Total } \\
(\mathrm{n}=157)\end{array}$ \\
\hline Atopy & $6(26.1 \%)$ & $15(21.1 \%)$ & $11(21.2 \%)$ & $3(27.3 \%)$ & $35(22.3 \%)$ \\
\hline Depression & $0(0 \%)$ & $7(9.9 \%)$ & $17(32.7 \%)$ & $3(27.3 \%)$ & $27(17.2 \%)$ \\
\hline Thyroid disorders & $1(4.3 \%)$ & $5(7.4 \%)$ & $18(34.6 \%)$ & $1(9.1 \%)$ & $25(15.9 \%)$ \\
\hline Dermatitis & $1(4.3 \%)$ & $8(11.3 \%)$ & $9(17.3 \%)$ & $0(0 \%)$ & $18(11.5 \%)$ \\
\hline Diabetes mellitus (type 1) & $1(4.3 \%)$ & $2(2.8 \%)$ & $0(0 \%)$ & $0(0 \%)$ & $3(1.9 \%)$ \\
\hline Diabetes mellitus (type 2) & $0(0 \%)$ & $0(0 \%)$ & $4(7.7 \%)$ & $0(0 \%)$ & $4(2.5 \%)$ \\
\hline Tumors & $0(0 \%)$ & $2(2.8 \%)$ & $3(5.8 \%)$ & $0(0 \%)$ & $5(3.2 \%)$ \\
\hline Lymphoma & $0(0 \%)$ & $1(1.4 \%)$ & $1(1.9 \%)$ & $0(0 \%)$ & $2(1.3 \%)$ \\
\hline Vitiligo & $1(4.3 \%)$ & $1(1.4 \%)$ & $1(1.9 \%)$ & $0(0 \%)$ & $3(1.9 \%)$ \\
\hline Psoriasis & $0(0 \%)$ & $1(1.4 \%)$ & $1(1.9 \%)$ & $0(0 \%)$ & $2(1.3 \%)$ \\
\hline IgA deficiency & $0(0 \%)$ & $0(0 \%)$ & $1(1.9 \%)$ & $0(0 \%)$ & $1(0.6 \%)$ \\
\hline Common variable immunodeficiency & $0(0 \%)$ & $0(0 \%)$ & $1(1.9 \%)$ & $0(0 \%)$ & $1(0.6 \%)$ \\
\hline Ulcerative colitis & $0(0 \%)$ & $1(1.4 \%)$ & 0 & $0(0 \%)$ & $1(0.6 \%)$ \\
\hline Down syndrome & $0(0 \%)$ & $0(0 \%)$ & $1(1.9 \%)$ & $0(0 \%)$ & $1(0.6 \%)$ \\
\hline
\end{tabular}

TABLE 2. Comparison of associated disorders in the studied patients

\begin{tabular}{|c|c|c|c|c|c|c|c|c|}
\hline \multirow[b]{2}{*}{ Compared groups } & \multicolumn{8}{|c|}{$P$ value } \\
\hline & Atopy & Depression & Thyroid disorders & Dermatitis & $\begin{array}{c}\text { Diabetes mellitus } \\
\text { (type 1) }\end{array}$ & $\begin{array}{c}\text { Diabetes mellitus } \\
\text { (type 2) }\end{array}$ & Tumor & Lymphoma \\
\hline Adolescent $\mathrm{x}$ young adult & 0.774 & 0.188 & 1 & 0.445 & 0.987 & - & 1 & 1 \\
\hline Adolescent $\mathrm{x}$ adult & 0.766 & $0.001 *$ & 0.004 & 0.161 & 0.307 & 0,306 & 0.548 & 1 \\
\hline Adolescent x elderly & 0.998 & 0.028 & 1 & 1 & 1 & - & - & - \\
\hline Young adult $\mathrm{x}$ adult & 1 & $0.002 *$ & $<0.001$ & 0.429 & 0.508 & 0,030 & 0.649 & 1 \\
\hline Young adult x elderly & 0.697 & 0.128 & 0.971 & 0.590 & 1 & - & 1 & 1 \\
\hline Adult $\mathrm{x}$ elderly & 0.695 & 1 & 0.150 & 0.339 & - & 1 & 1 & 1 \\
\hline
\end{tabular}

Fisher's exact test, $P<0.008$ (Bonferroni correction)

*statistical significance

TABLE 3. Number of associated disorders in the studied patients

\begin{tabular}{|c|c|c|c|c|c|}
\hline Number of associated diseases & $\begin{array}{c}\text { Group I } \\
\text { Adolescent } \\
(\mathrm{n}=23)\end{array}$ & $\begin{array}{l}\text { Group II } \\
\text { Young adult } \\
(\mathrm{n}=71)\end{array}$ & $\begin{array}{l}\text { Group III } \\
\text { Adult } \\
(\mathrm{n}=52)\end{array}$ & $\begin{array}{c}\text { Group IV } \\
\text { Elderly } \\
(\mathrm{n}=11)\end{array}$ & $\begin{array}{c}\text { Total } \\
(\mathrm{n}=157)\end{array}$ \\
\hline 0 & $14(60.9 \%)$ & $29(40.8 \%)$ & $11(21.2 \%)$ & $4(36.4 \%)$ & $58(36.9 \%)$ \\
\hline 1 & $9(39.1 \%)$ & $35(49.3 \%)$ & $23(44.2 \%)$ & $6(54.5 \%)$ & $73(46.5 \%)$ \\
\hline 2 & $0(0 \%)$ & $6(8.5 \%)$ & $11(21.2 \%)$ & $1(9.1 \%)$ & $18(11.5 \%)$ \\
\hline 3 & $0(0 \%)$ & $1(1.4 \%)$ & $6(11.5 \%)$ & $0(0 \%)$ & $7(4.5 \%)$ \\
\hline 4 & $0(0 \%)$ & $0(0 \%)$ & $1(1.9 \%)$ & $0(0 \%)$ & $1(0.6 \%)$ \\
\hline Mean & 0.39 & 0.70 & 1.29 & 0.73 & 0.85 \\
\hline
\end{tabular}


TABLE 4. Comparison between the number of associated disorders in the studied patients

\begin{tabular}{lc}
\hline Compared groups & $\boldsymbol{P}$ value \\
\hline Adolescent x young adult & 0.086 \\
Adolescent x adult & $<0.001^{*}$ \\
Adolescent x elderly & 0.201 \\
Young adult x adult & $0.002^{*}$ \\
Young adult x elderly & 0.862 \\
Adult x elderly & 0.106 \\
\hline
\end{tabular}

Complications concerning bone disease are shown in Table 5, revealing changes since adolescence. Considering adolescents and young adults $(\mathrm{n}=22)$, femur disease was found in $16(72.7 \%)$ and spinal cord disease in $18(81.8 \%)$. Adults and elderly together $(n=30)$ presented $86.7 \%$ of bone disease in the femur and in the spinal cord. There was no statistical significance between the groups (femur $P=0.290$; spinal cord: $P-0.708)$.

TABLE 5. Findings of bone disorders detected by DEXA in the studied patients

\begin{tabular}{lcccc}
\hline DEXA at diagnosis & $\begin{array}{c}\text { Group I } \\
\text { Adolescent } \\
(\mathbf{n}=2)\end{array}$ & $\begin{array}{c}\text { Group II } \\
\text { Young adult } \\
(\mathbf{n}=20)\end{array}$ & $\begin{array}{c}\text { Group III } \\
\text { Adult } \\
(\mathbf{n}=27)\end{array}$ & $\begin{array}{c}\text { Group IV } \\
\text { Elderly } \\
(\mathbf{n}=3)\end{array}$ \\
\hline Osteopenia: femur & $2(100 \%)$ & $12(60.0 \%)$ & $16(59.3 \%)$ & $0(0 \%)$ \\
Osteoporosis: femur & $0(0 \%)$ & $2(10.0 \%)$ & $7(25.9 \%)$ & $3(100 \%)$ \\
Osteopenia: spinal cord & $0(0 \%)$ & $13(65.0 \%)$ & $14(51.9 \%)$ & $0(0 \%)$ \\
Osteoporosis: spinal cord & $0(0 \%)$ & $5(25.0 \%)$ & $9(33.3 \%)$ & $3(100 \%)$ \\
\hline
\end{tabular}

Gynecologic and obstetric information are listed in Table 6 emphasizing the occurrence of spontaneous abortion. Even without statistical significance, adults showed tendency to have more spontaneous abortion (Table 7).

TABLE 6. Gynecologic and obstetric data of the studied patients

\begin{tabular}{lcccc}
\hline Gynecologic/obstetric & $\begin{array}{c}\text { Group I } \\
\text { Adolescent } \\
(\mathbf{n}=2)\end{array}$ & $\begin{array}{c}\text { Group II } \\
\text { Young adult } \\
(\mathbf{n}=37)\end{array}$ & $\begin{array}{c}\text { Group III } \\
\text { Adult } \\
(\mathbf{n}=34)\end{array}$ & $\begin{array}{c}\text { Group IV } \\
\text { Elderly } \\
(\mathbf{n}=5)\end{array}$ \\
\hline Number of pregnancies & 0 & 74 & 108 & 19 \\
Pregnancies / woman & 0 & 2.0 & 3.2 & 3.8 \\
Number of abortions & 0 & $20(27.0 \%)$ & $15(13.9 \%)$ & $5(26.3 \%)$ \\
\hline
\end{tabular}

TABLE 7. Comparison between the groups of the patients studied, concerning the number of spontaneous abortion

\begin{tabular}{lc}
\hline Compared groups & $\boldsymbol{P}$ value \\
\cline { 2 - 2 } & Abortion \\
\hline Adolescent x young adult & 1 \\
Adolescent x adult & 1 \\
Adolescent x elderly & 1 \\
Young adult x adult & 0.035 \\
Young adult x elderly & 1 \\
Adult x elderly & 0.180 \\
\hline Fisher's exact tess, $P<0.00$ (Bonferroni correction) &
\end{tabular}

One adolescent patient died due type 1 diabetes mellitus complications. In young adults the causes of death were one lymphoma, one acute meningitis and one suicide.

\section{DISCUSSION}

Five patients $(3.18 \%)$ were diagnosed with $\mathrm{CD}$ during adolescence. This is in accordance with the literature pointing out that in this period CD is not commonly diagnosed, and can present atypical forms, or can be asymptomatic ${ }^{(55)}$.

Despite classical manifestations of CD in the elderly, the diagnosis was made only in five $(3.18 \%)$ patients over 65 years of age. GASBARRINI et al. ${ }^{(25)}$ reported $4.4 \%$, in Italy. Recently in the UK, HOLMES ${ }^{(33)}$ reported $1 / 3$ of the patients diagnosed as celiacs at an advanced-age. The shortening of life expectancy of elderly patients emphasizes the importance of considering $\mathrm{CD}$ as a possible diagnosis by physicians. SANDERS et al. ${ }^{(56)}$ call attention to the fact that antibody negative CD can be detected in the elderly, leading to missed diagnose. Earlier treatment with a GFD might also protect these patients from developing malignant complications with age.

The increased proportion of diagnosis of $\mathrm{CD}$ in the seventh decade may reflect either an increased interest in $\mathrm{CD}$ or a true increase of incidence. SWINSON and LEVI ${ }^{(62)}$ showed a bimodal distribution with a peak in the fourth decade mainly in women and a later peak in the sixth and seventh decades consisting mainly of men, similar to the present study.

In adults $\mathrm{CD}$ is more frequent in women. The overall female/male ratio was $1.3: 1^{(28)}$ as is demonstrated in this study $(79.6 \% \text { women x } 20.4 \% \text { men })^{(26)}$.

\section{Associated disorders}

COOPER et al. ${ }^{(14)}$ pointed out that autoimmune disorders appeared more often in patients with $\mathrm{CD}$ than in the normal population. Most of these immunological disorders developed when the patients were on a normal diet, however a GFD did not prevent their development and had little amelioration effect on the course apart from an occasional dramatic improvement in atopic patients. Older untreated CD patients have a higher prevalence of autoantibodies than younger patients, suggesting that the duration of gluten exposure increases the risk of developing autoantibodies ${ }^{(68)}$. The results of the present study are in accordance with this hypothesis (Tables 1, 2 and 3).

Some reasons for the associations of autoimmune diseases may be that $C D$ and these other disorders share similar autoimmune pathogenic mechanisms, or that the same gene is responsible for a proportion of these disorders. It is possible that chronic lymphocyte stimulation in the intestine in $\mathrm{CD}$ could result in an increase in autoantibody production and therefore stimulate the development of other autoimmune disorders ${ }^{(61)}$.

\section{Atopy}

In our study atopy was present in all the groups (Table 1). BOTTARO et al. ${ }^{(6)}$ analyzing 1,026 consecutive cases of 
subclinical/silent CD, in Italy, showed that another disease was found in $30.1 \%$ of adults and in $20.6 \%$ of children, diabetes and atopy being the most frequently associated conditions in both children and adults. Children with CD were significantly more often atopic. Atopy was more frequent at the onset of CD.

ZAULI et al. ${ }^{(75)}$ demonstrated that the prevalence of $\mathrm{CD}$ in atopics is $1 \%$ which is significantly higher than in the general Italian population. Therefore, atopy should be considered as a risk and atopic patients should be screened by means of specific autoantibody testing, if pertinent.

VERKASALO et al. ${ }^{(69)}$, studying children and adolescents, concluded that atopy predisposes CD partly independently of the HLA-DR3 associated disease susceptibility gene(s), and that different mechanisms may operate in the pathogenesis in $\mathrm{CD}$ patients with and without atopy. A deficiency of local mucosal immunity due to abnormal IgA response may underly the association of $\mathrm{CD}$ with atopy ${ }^{(30)}$.

\section{Dermatological disorders}

At present, dermatitis herpetiformis $(\mathrm{DH})$ is considered a cutaneous manifestation of $\mathrm{CD}$, affecting approximately $25 \%$ of patients with $\mathrm{CD}$. The common age at onset of $\mathrm{DH}$ is 30-40 years but can appear in childhood or at older ages and there is predominance in $\operatorname{men}^{(13)}$. In the present study DH was detected in $11.5 \%(18 / 157)$, in 14 females and 4 males, similar in percentage to patients from ages 21 to 59 years of age (Table 1).

In patients with $\mathrm{DH}$ the risk for intestinal lymphoma is significantly increased when the diet is neglected for a long period, particularly in the elderly ${ }^{(29)}$. One patient of the present study presented B-cell lymphoma at 54 years of age and was diagnosed as having $\mathrm{CD}$ and $\mathrm{DH}$ at the age of 33 years. The patient strictly adhere to a GFD and showed negative IgA EmA. Thus, the percentage of 5.5\% (1/18) in our study is indeed elevated. This question of a protective effect of a GFD against the development of lymphoma in $\mathrm{DH}$, as reported by LEWIS et al. ${ }^{(45)}$.

Vitiligo and psoriasis are autoimmune skin diseases reported in association with CD and DH. Three females (17, 28 and 52 years old) presented vitiligo with CD (1.9\%). REUNALA and COLLIN ${ }^{(54)}$ reported $1.6 \%$ of vitiligo in $\mathrm{DH}$.

Psoriasis was detected in two females (34 and 43 years of age) with CD $(1.3 \%)$ (Table 1) and presented marked improvement of the skin lesions after a GFD. Psoriasis can be defined as a T-cell-mediated disorder resembling CD. At present, the mechanisms implicated in the possible association between $\mathrm{CD}$ and psoriasis and in the effect of GFD on psoriatic skin lesions are not known ${ }^{(1)}$.

The association of these dermatological conditions with $\mathrm{CD}$ is considered coincidental by some authors ${ }^{(19)}$ and with immunological implications by others ${ }^{(71)}$.

\section{Endocrinological disorders}

Diabetes mellitus and CD are both autoimmune disorders, associated with HLA markers B8 and DR3, sharing the same high-risk HLA DQ2 genotype. The frequency of insulin dependent diabetes mellitus (IDDM) in CD is $1 \%$ to $7 \%$, which is increased when compared to the general population ${ }^{(32)}$. Approximately $4 \%$ of patients with IDDM have concomitant $\mathrm{CD}^{(30,59)}$. In Brazil, TANURE et al. ${ }^{(64)}$ reported a prevalence of $2.6 \%$ among 234 children and adolescents with IDDM using $\mathrm{IgA}$ and $\mathrm{IgG}$ antigliadin antibodies (AGA) followed by $\operatorname{IgA}$ EmA.

In the present study there were $1.9 \%$ with IDDM (3/155), ages 12, 21 and 31 years. Death occurred in the youngest due to diabetic complications. In all cases, the diagnosis of IDDM preceded the diagnosis of CD.

Non-insulin dependent diabetes mellitus (NIDDM) were detected in $2.5 \%(4 / 157)$. Diabetes was diagnosed prior to $\mathrm{CD}$ in one case, and following CD in the other three. All of these patients were between 40-50 years of age. PAGE et al. ${ }^{(52)}$ referred to a 1:50 proportion in adults with $C D$ and IDDM, and a 1:340 ratio in NIDDM, in the UK, using IgA AGA as the serologic test. SJÖBERG et al. ${ }^{(60)}$ recommended screening with IgA EmA in patients with IDDM, due to the fact that AGA false-positive results can occur. The patients of the present study were screened with $\operatorname{IgA}$ EmA.

Thyroid diseases are the most common autoimmune diseases detected in CD, as we demonstrated in a previous study $^{(42)}$. The risk of thyroid disease among CD patients had been estimated to be almost 3-fold higher than that of the general population ${ }^{(57)}$. In this study hyperthyroidism was detected in $0.6 \%(1 / 157)$, subclinical hypothyroidism in $6.4 \%(10 / 157)$ and clinical hypothyroidism in $8.9 \%(14 / 157)$. The total of thyroid involvement was $15.9 \%$ (Table 1$)$. The prevalence of these disorders increases with age ${ }^{(57)}$ as is evident in Table 1, more in adults.

As CD and thyroid diseases have a female preponderance it is important to screen for thyroid dysfunction in patients with CD independently of age at diagnosis or treatment with a $\mathrm{GFD}^{(42)}$. LEEDS et al. ${ }^{(44)}$ recommended routine yearly thyroid function tests. Another important fact is that a GFD promotes better absorption of thyroxine, improving the clinical control of hypothyroidism ${ }^{(35)}$.

In relation to the finding of a medullary thyroid carcinoma, there are no other reports concerning the association with $\mathrm{CD}^{(42)}$

\section{Psychiatric disorders}

Psychiatric disorders were reported in CD, predominantly depression, in association (or complication) with CD, occurring in about one third of the patients ${ }^{(12)}$. In the present study this diagnosis occurred in $17.2 \%$. Adults presented more depression, with statistical significance. In adolescents there were no reports of depression, only anxiety and irritability ${ }^{(37)}$.

The mechanisms of depression remain unclear: malabsorption and nutritional deficiencies (B6 vitamin and tryptophan) or association with other autoimmune disease (thyroid disorders) could be causative factors. It appears that disturbances in serotoninergic regulation can give rise to both mood and aggression disorders. The patient that committed suicide suffered from severe depression, medullary carcinoma of the thyroid surgically treated, and refused drugs for the treatment of depression. 
Association with subclinical thyroid disease could represent a significant risk factor for psychiatric disorders. However, in our study patients presented depression with normal thyroid evaluation and others with overt hypothyroidism did not present depression. Only few received antidepressants for a short period of time.

\section{Miscellaneous}

Selective IgA deficiency was detected in one female ( 54 years) with $\mathrm{CD}, \mathrm{DH}$ and hypothyroidism. The serologic tests EmA and anti-tTG were performed with $\operatorname{IgG}^{(18)}$ and the screening of the family showed that the two sons and two daughters presented IgA deficiency. The IgG EmA and anti-tTG were also positive in one son, with villous atrophy at intestinal biopsy. The sharing of a similar HLA haplotype may partly explain the strong association between $\operatorname{IgA}$ deficiency and $\mathrm{CD}$.

Common variable immunodeficiency and $\mathrm{CD}$ was detected in one female (52 years old), with $\mathrm{CD}, \mathrm{DH}$, vitiligo, recurrent respiratory infections and asthma. She presented chronic symptoms of malabsorption due to total villous atrophy of the intestinal mucosa. The symptoms disappeared and the histologic abnormalities improved after a GFD and the use of immunoglobulin ${ }^{(41)}$. This association should not be considered fortuitous, considering that serologic tests are of low sensitivity in this setting ${ }^{(4)}$.

The persistence of gastrointestinal symptoms after gluten withdrawal and strict adherence to a GFD (IgA EmA negative) was observed in one female (63 years old) that improved after the use of antibiotics, suggesting the diagnosis of small intestinal bacterial overgrowth ${ }^{(66)}$.

Conflicting studies exist examining the relationship between $\mathrm{CD}$ and inflammatory bowel disease (IBD). In the present study only one woman presented ulcerative colitis before the diagnosis of $\mathrm{CD}$, with pANCA positive. The treatment with 5-ASA induced remission. HOROLDT et al. ${ }^{(34)}$ reported that the patients with $\mathrm{CD}$ have an 8 times increased risk of developing IBD compared to healthy controls, but IBD patients have no increased risk of developing CD.

A high prevalence of CD in patients with Down's syndrome (DS) has been reported, but mainly in children. In this experience a woman, 47 year-old, with DS, hypothyroidism and previous treatment for pulmonary tuberculosis presented gastrointestinal complaints and was diagnosed as having $\mathrm{CD}$. A GFD controlled the hypothyroidism and reverted the GI symptoms ${ }^{(43)}$. Nowadays, the individuals with DS can live 50 years or more and can have autoimmune diseases, such as $\mathrm{CD}$. Both DS and CD can also predispose the patients to malignancies, particularly in adult life.

\section{Complications}

Some authors do not consider anemia, bone disease and gynecologic problems as complications of $\mathrm{CD}$, but only symptoms and clinical signs that can suggest the existence of $C D$.

\section{Anemia}

Anemia is one of the most frequent symptoms/signs of $\mathrm{CD}$. Iron deficiency is the predominant cause and the most frequent manifestation in the subclinical and silent form of disease, even in well nourished patients ${ }^{(40)}$. GFD has been shown to restore both anemia and iron deficiency, thus making iron supplementation unnecessary for all patients. Vitamin B12 and folate deficiencies are also common and may require additional supplementation.

In the present study, at diagnosis, a high percentage of anemia was detected in all groups, independently of age or severity of the clinical manifestations, without statistical significance.

\section{Bone disease}

Most studies that have assessed the BMD in CD patients have reported a low bone mass in both adults and children ${ }^{(50)}$. In São Paulo, Brazil, SDEPANIAN et al ${ }^{(58)}$, in 13 adolescents with $\mathrm{CD}$ reported that BMD was lower than that of the controls. Furthemore, the proportion of adolescents who had started a GFD after 2 years of age was higher than that of children with $\mathrm{CD}$, an experience similar to ours.

Measurement of BMD is recommended when $\mathrm{CD}$ has been diagnosed. In the present study it was possible to determine BMD at diagnosis in 53 patients (Table 5). In adolescents and young adults we found bone disease in $72.7 \%$ in femur and in $81.8 \%$ in the spinal cord. Even without statistical significance, we call attention for the tendency of early bone involvement in the young celiacs.

A very high frequency of osteopenia and osteoporosis was detected in older patients, specifically with respect to post-menopausal women. CHIECHI et al. ${ }^{(11)}$ emphasized that $\mathrm{CD}$ is a predisposing condition not commonly considered for postmenopausal diseases, such as postmenopausal osteoporosis.

In the United States BMD was normal in only $25 \%$ of patients with $\mathrm{CD}, 45 \%$ presenting more than one standard deviation below age matched controls ${ }^{(51)}$. Men were more severely affected than women. In our study there was a female preponderance and the results differed from the above cited findings.

The pathogenesis of low bone mass and osteoporosis in $\mathrm{CD}$ is multi-factorial and not completely understood. Calcium malabsorption with hyperparathyroidism, malabsorption of vitamin D, increased inflammatory cytokines (IL-1 and IL-6) play a strong role in bone resorption and are therefore important factors to be considered. Bone fractures are a consequence of bone weakness related to the severity of CD activity ${ }^{(51)}$.

In the treatment of $\mathrm{CD}$ a strict adherence to a GFD is emphasized. It is also reasonable to recommend maximizing general measures such as adequate calcium and vitamin D intake, and physical activities, and to control other minor risk factors such as smoking.

\section{Spontaneous abortion}

The number of pregnancies per female was similar in all the groups, except in group IV as one woman reported 11 pregnancies with 6 spontaneous abortions (Table 6). As a consequence of numerous miscarriages, the patients repeated attempts to become pregnant. This fact corroborates the idea 
that the women with $\mathrm{CD}$ were not infertile ${ }^{(40,65)}$. The number of pregnancies was higher in patients diagnosed as celiacs between 40 to 60 years of age, probably due to a delayed diagnosis of $\mathrm{CD}^{(65)}$.

The number of spontaneous abortions in each group (Table 6) was significantly increased with respect to the Brazilian healthy population $(6.0 \%)^{(21)}$. In a previous study we demonstrated that it was not related to nutritional status nor to the severity of $\mathrm{CD}^{(40)}$. FOSCHI et al. ${ }^{(22)}$ emphazised that women experiencing spontaneous abortion can have an atypical form of $\mathrm{CD}$. This could be concluded in the groups of patients that did not know that they had CD.

Table 7 shows the comparison between the groups. There was no statistical significance but there was a tendency to increased number of spontaneous abortion in the adults.

The reasons for the increased number of spontaneous abortion is speculative, however the presence of gluten in the diet could be important, since after a GFD the number of pregnancies is similar, yet the number of spontaneous abortions decreases substantially ${ }^{(40)}$.

\section{Malignancies}

Patients with CD carry a considerable risk of gastrointestinal malignancies, particularly non-Hodgkin's lymphoma (NHL) that represents the most serious complication of the disease $\mathrm{e}^{(46)}$. Commonly, patients present deterioration symptoms of the underlying disease, making an early diagnosis difficult ${ }^{(7,23,63)}$.

\section{Lymphomas}

New studies seem to indicate that $\mathrm{CD}$ is associated with significantly increased risk for NHL, especially the T-cell type and primarily located in the gut (EATL $)^{(8)}$. Many studies evaluating the frequency of the association lymphoma-CD, particularly those analyzing the causes of death in celiac patients, could only label cases as "lymphoma", as the primary site of the tumor was often not specified on the individual records. Therefore, it is not clear whether the association is with T-cell lymphoma or with NHL, including the more common forms of B-cell origin, both nodal and extranodal ${ }^{(8)}$. MEARIN et al. ${ }^{(49)}$ reported $2.6 \%$ presence of NHL in patients with CD diagnosed before the study, but not in those with silent CD detected by screening.

In our study two cases of lymphoma were diagnosed (2/157 or $1.27 \%$ ). One male patient, strictly adherent to a GFD, IgA EmA negative, died at the age of 33 years from "lymphoma" (unclassified due to missing material). The other patient, with $\mathrm{DH}$ and $\mathrm{CD}$, diagnosed at 33 years of age, compliant to a GFD, IgA EmA negative, and without the use of dapsone, was diagnosed as having B-cell lymphoma (follicular type) at 54 years of age and is currently receiving chemotherapy. HERVONEN et al. ${ }^{(29)}$ reported $1 \%$ lymphoma in patients with DH that contracted the malignancy 2-31 years after the diagnosis of DH. A recent Swedish cohort study ${ }^{(73)}$ raised the possibility of an increased risk for B-cell NHL in patients primarily affected with $\mathrm{CD}$. However, the exact prevalence of lymphoma in $\mathrm{CD}$ is difficult to determine, in part because it can arise in patients with silent or previously undiagnosed CD.
Asymptomatic high-risk patients with chronically altered mucosa may be detected earlier. It should be noted that histological recovery after starting a GFD takes time (more than 2 years in $35 \%$ of the patients) and that $10 \%$ of the patients present incomplete or non recovery. The risk of this group of patients developing a malignant neoplasma is undefined thus far, and should be further investigated ${ }^{(72)}$.

One strategy to identify patients at risk of development of a neoplasma may be regular re-endoscopy to confirm persistent normalization of the intestinal mucosa after the elimination of gluten from the diet. The patients of our study were controlled by endoscopy and histology, as well as imaging techniques (ultra-sound, computed tomography or magnetic resonance). Recently, the use of endoscopic capsule (wireless endoscopic capsule - WEC) was recommended in suspect cases of neoplasma in celiac patients ${ }^{(16)}$.

\section{Other malignancies}

In most cases of malignancy associated with $\mathrm{CD}$, malignancy was discovered many years before $\mathrm{CD}$. However, the patients could also experience symptoms that in retrospect were caused by $\mathrm{CD}$. In general, identifying the time of the onset of CD is difficult because there is usually a long silent or asymptomatic period. Even when symptoms develop, patients often receive other diagnose ${ }^{(5)}$. This occurred in two patients of the present study: the diagnosis of $\mathrm{CD}$ was made after the treatment for breast cancer, in the premenopausal period. The percentage of breast cancer was $1.9 \%(3 / 157)$, different from WEST et al. ${ }^{(73)}$ in the UK, and ASKLING et al..$^{(3)}$ in Sweden, who reported a noticeably reduced risk of breast cancer, both for pre- and postmenopausal cases. The mechanisms involved are not well understood.

Medullar carcinoma of the thyroid was detected in one female at the time of CD diagnosis, treated by surgery ${ }^{(42)}$. Gastrointestinal stromal tumor (GIST) was diagnosed in another female after the diagnosis of CD. She is currently receiving systemic therapy with imatinib, a tyrosine kinase inhibitor ${ }^{(48)}$. In the literature there is no reference to either of these tumors in association with CD.

The malignancies can be detected before, during or after the diagnosis of $\mathrm{CD}^{(27)}$. In the present experience (Table 1, total 3.2\%) two cases of breast cancer were detected before, one medullary carcinoma of the thyroid gland was diagnosed during the diagnosis of $\mathrm{CD}$, and two lymphomas, one breast cancer and one GIST were detected after the diagnosis of $\mathrm{CD}$, even on a GFD.

Two important questions arise. First, is $\mathrm{CD}$ a premalignant condition? Abnormal intra-epithelial lymhocytes may disseminate and progress to an overt malignant disorder secondary to a self-sustained inflammatory process. It is likely that a continuum of autoimmune enteropathy progresses to a monoclonal malignant disorder ${ }^{(9)}$.

Second, does the GFD protect against cancer development? There is much controversy concerning this issue ${ }^{(31,47)}$. Cancer can arise in patients treated with a GFD sometimes for years, apparently refuring any beneficial effect of dietary treatment of $\mathrm{CD}$ on cancer risk. However, many of these 
patients had previously been exposed to dietary gluten for a long time, and a short period on GFD. Thus, this brief period could be insufficient to reverse the deleterious effects of exposure to an oncogenic stimulus. The study in Sweden clearly showed that the overall relative risk for cancer declined with the increasing length of follow-up evaluation. After 2 years of treatment the risk was only slightly and non significantly elevated. In conclusion, currently, strict adherence to the GFD seems to be the only possibility for prevention of a subset of rare but very aggressive forms of cancer.

\section{Mortality and causes of death}

The overall mortality in CD is approximately twice that of the general population, with an increase occurring predominantly within the first year after diagnosis ${ }^{(47)}$. The excess deaths are due mainly to malignancies with intestinal lymphoma. COTTONE et al. ${ }^{(15)}$ in 228 adults with CD from a Mediterranean population, reported 12 deaths, 12 tumors, 6 non-Hodgkin lymphomas. The interval between the diagnosis of CD and death was 4 year. PETERS et al. ${ }^{(53)}$ in a Swedish population reported that 828 patients with $\mathrm{CD}$ died between 1965-1994: non-Hodgkin lymphoma, cancer of the small intestine, autoimmune diseases as rheumatoid arthritis, diffuse disease of connective tissue, or allergic disorders (such as asthma), inflammatory bowel diseases, diabetes mellitus, disorders of immune deficiency, tuberculosis, pneumonia and nephritis. In summary, elevated mortality risk for all causes of death combined reflected, for the most part, disorders characterized by immune dysfunction. Similarly, in our study four deaths occurred (2.5\%): one IDDM complications, one lymphoma, one depression with suicide and one with acute meningitis.

\section{CONCLUSIONS}

In summary, this experience is similar to those described in the world literature, suggesting that CD may have the same characteristics regardless of the country or region studied.

Primary care physicians and specialists should increase consideration of $\mathrm{CD}$ as a possible diagnosis in several clinical situations $^{(76)}$. They must recommend a strict adherence to a GFD for patients with CD, and be aware of the appearance of autoimmune diseases ${ }^{(67)}$. In addition, professionals should re-study the patients with different symptoms or clinical deterioration with the objective of an early diagnosis of malignancies ${ }^{(72)}$.

All the findings described in this report compel us to recommend a periodic evaluation of complications and associated disorders in CD, from childhood, independent of the age at diagnosis or the duration of a GFD. The goal is to establish an appropriate interval between the evaluations: not only when the patient presents symptoms, but routinely.

\section{ACKNOWLEDGMENTS}

The author thanks Doctors Shirley Ramos da Rosa Utiyama and Renato Mitsunori Nisihara for the autoantibodies determinations, and Professor Márcia Olandoski for the statistical analysis.

Kotze LMS. Doença celíaca em pacientes brasileiros: associações, complicações e causas de morte. Quarenta anos de experiência clínica. Arq Gastroenterol. 2009;46(4):261-9.

RESUMO - Contexto - A doença celíaca é uma enfermidade multissistêmica e autoimune que pode se manifestar em qualquer idade, em indivíduos geneticamente predispostos. Objetivo - Identificação das associações, complicações e causas de morte em pacientes brasileiros após longo período de acompanhamento. Métodos - Foram estudados retrospectivamente 157 pacientes, 23 adolescentes e 134 adultos, 79,6\% do sexo feminino e 20,4\% do masculino, $75,8 \%$ ao diagnóstico e 24,2\% em dieta isenta de glúten, com seguimento de 3 a 40 anos. O diagnóstico de doença celíaca se baseou na presença de autoanticorpos marcadores de doença celíaca no sangue periférico e dados histológicos da mucosa intestinal. Exames específicos para associações foram realizados conforme suspeita clínica. Densitometria óssea foi realizada em 53 dos pacientes por ocasião do diagnóstico. Os achados referentes às associações, complicações e causas de morte foram obtidos através de entrevistas e revisão de prontuários. Resultados Associações diagnosticadas: atopia (22,3\%), depressão (17,2\%), afecções tireoidianas (15,9\%), dermatite herpetiforme (11,5\%), diabetes mellitus tipos 1 e $2(4,5 \%)$ e tumores $(4,5 \%)$. Complicações: anemia e osteopenia/osteoporose em todos os grupos; aumento do número de abortos espontâneos. Quatro pacientes $(4,5 \%)$ foram a óbito: um por linfoma, um adolescente por complicações de diabetes tipo 1, um homem por meningite aguda e uma paciente se suicidou. Conclusões - A experiência relatada é semelhante às descritas na literatura mundial, deduzindo-se que a doença celíaca apresenta características semelhantes independente da área geográfica. Recomenda-se avaliações periódicas, desde a infância, independente da idade ao diagnóstico e duração da dieta. A dificuldade é se estabelecer intervalo adequado entre estas avaliações.

DESCRITORES - Doença celíaca. Gluten. Linfoma não-Hodgkin.

\section{REFERENCES}

1. Addolorato G, Parente A, de Lorenzi G, DiPaola ME, Abenavoli L, Leggio L, Capristo E, De Simone C, Rotoli M, Rapaccini GL, Gasbarrini G. Rapid regression of psoriasis in a coeliac patient after gluten-free diet. Digestion. 2003;68:9-12.

2. Alaedini A, Green PHR. Narrative review: celiac disease: understanding a complex autoimmune disorder. Ann Intern Med. 2005;142:289-98.
3. Askling J, Linet M, Gridley G, Halstensen TS, Ekstrom K, Ekbom A. Cancer incidence in a population-based cohort of individuals hospitalized with celiac disease or dermatitis herpetiformis. Gastroenterology. 2002;123:1428-35.

4. Bechade D, Desrame J, De Fuentes G, Camparo P, Raynaud JJ, Algayres JP. Common variable immunodeficiency and celiac disease. Gastroenterol Clin Biol. 2004;28:909-12.

5. Bhagat G, Leffler D, Bilezikian JP, Green PHR. Cystosarcoma phyllodes of the 
breast occurring in a child with subsequent diagnosis of celiac disease. J Pediatr Gastroenterol Nutr. 2003;36:644-6.

6. Bottaro G, Cataldo F, Rotolo N, Spina M, Corazza GR. The clinical pattern of subclinical/silent celiac disease: an analysis on 1026 consecutive cases. Am J Gastroenterol. 1999;94:691-6.

7. Buess M, Steuerwald M, Wegmann W, Rothen M. Obstructive jaundice caused by enteropathy-associated T-cell lymphoma in a patient with celiac sprue. J Gastroenterol. 2004;29:1110-3.

8. Catassi C, Fabiani E, Corrao G, Barbato M, De Renzo A, Carella AM, Gabrielli A, Leoni P, Carroccio A, Baldassarre M, Bertolani P, Caramaschi P, Sozzi M, Guariso G, Volta U, Corazza GR. Risk of non-Hodgkin lymphoma in celiac disease. JAMA. 2002;287:1413-9.

9. Cellier C, Delabesse E, Helmer C, Patey N, Matuchansky C, Jabri B, MacIntyre E, Cerf-Bensussan N, Brousse N. Refractory sprue, celiac disease, and enteropathyassociated T-cell lymphoma. Lancet. 2000;356:203-8.

10. Chand N, Mihas AA. Celiac disease: current concepts in diagnosis and treatment. J Clin Gastroenterol. 2006;40:3-14.

11. Chiechi LM, Valerio T, Loizzi P. Postmenopausal osteoporosis and celiac disease. Clin Exp Obstet Gynecol. 2002;29:187-8.

12. Ciacci C, Iavarone A, Mazzacca G, De Rosa A. Depressive symptoms in adult coeliac disease. Scand J Gastroenterol. 1998;33:247-50.

13. Collin P, Reunala T. Recognition and management of the cutaneous manifestations of celiac disease. A guide for dermatologists. Am J Dermatol. 2003;4:13-20.

14. Cooper BT, Holmes GK, Cooke WT. Coeliac disease and immunological disorders. Br Med J. 1978;1:537-9.

15. Cottone M, Termini A, Oliva L, Magliocco A, Marrone C, Orlando A, Pinzone F, Di Mitra R, Rosselli M, Rizzo A, Pagliaro L. Mortality and causes of death in celiac disease in a Mediterranean area. Dig Dis Sci. 1999;44:2538-41.

16. Culliford A, Daly J, Diamond B, Rubin M, Green PH. The value of wireless capsule endoscopy in patients with complicated celiac disease. Gastrointest Endosc. 2005;62:55-61.

17. Cullum ID, Ell PJ, Ryder JP. X-ray dual-photon absorptiometry: a new method for the measurement of bone density. Br J Radiol. 1989;62:587-92.

18. Dahlbom I, Olsson M, Forooz NK, Sjoholm AG, Truedson L, Hanson T. Immunoglobulin $\mathrm{G}(\mathrm{IgG})$ anti-tissue transglutaminase antibodies used as markers for IgA-deficient celiac disease patients. Clin Diagn Lab Immunol. 2005;12:254-8.

19. de Vos RJ, de Boer WA, Hass FD. Is there a relationship between psoriasis and coeliac disease? [letter]. J Intern Med. 1995;237:118.

20. Dieterich W, Laag E, Schopper H. Autoantibodies to tissue transglutaminase as predictors of celiac disease. Gastroenterology. 1998;115:1317-21.

21. Dotta IG, Noda E, Silva SII. Adolescent pregnancy. Rev Bras Med. 2000;57: $15-22$.

22. Foschi F, Diani F, Zardini E, Zanoni G, Caramaschi P. Celiac disease and spontaneous abortion. Minerva Ginecol. 2002;54:151-9.

23. Freeman HJ. Lymphoproliferative and intestinal malignancies in 214 patients with biopsy-defined celiac disease. J Clin Gastroenterol. 2004;38:429-34.

24. Freitag T, Schuppan D. Screeening for celiac disease. Antigen source and performance of the anti-tissue transglutaminase ELISA. Dig Liver Dis. 2004;36:658-60.

25. Gasbarrini G, Ciccocioppo R, De Vitis I, Corazza GR. Coeliac disease in the elderly. Gerontology. 2002;47:306-10.

26. Green PHR, Stravropoulos SN, Panagi SG, Goldstein SL, McMahon DJ, Absam $\mathrm{H}$, Neuqut AI. Characteristics of adult celiac disease in the USA: results of a national survey. Am J Gastroenterol. 2001;96:126-31.

27. Green PH, Fleischauer AT, Bhagat G, Goyal R, Jabri B, Neuqut AI. Risk of malignancy in patients with celiac disease. Am J Med. 2003;115:191-5.

28. Green PHR, Cellier C. Celiac disease. N Engl J Med. 2007;357:1731-43.

29. Hervonen K, Vornanen M, Kautiainen H, Collin P, Reunala T. Lymphoma in patients with dermatitis herpetiformis and their first-degree relatives. $\mathrm{Br} \mathbf{J}$ Dermatol. 2005;152:82-6.

30. Hodgson HJ, Davies RJ, Gent AE. Atopic disorders and adult celiac disease. Lancet. 1976;1:115-7.

31. Holmes GKT, Prior P, Lane MR, Pope D, Allan RN. Malignancy in celiac disease - effect of a gluten-free diet. Gut. 1989;30:333-8.

32. Holmes GK. Coeliac disease and type 1 diabetes mellitus: the case for screening. Diabet Med. 2001;18:169-77

33. Holmes GKT. Coeliac disease in a single centre 1975-2004 [abstract]. (Presented at XII International Celiac Disease Symposium; 2006 November 9-11; New York, NY. Abstract D-280, p.96).

34. Horoldt BS, Leeds JS, Sidhu R, Hopper AD, Robinson K, Toulson B, Lobo AJ, McAlindon ME, Hurlstone DP, Sanders DS. Is there a relationship between celiac disease and inflammatory bowel disease? A bidirectional prevalence study with controls [abstract]. (Presented at XII International Celiac Disease Symposium; 2006 November 9-11; New York, NY. Abstract D-291, p.102).

35. Jiskra J, Limanová Z, Vanicková Z, Kocna P. IgA and IgG antigliadin, IgA anti- tissue transglutaminase and antiendomysial antibodies in patients with autoimmune thyroid diseases and their relationship to thyroidal replacement therapy. Physiol Res. 2003;52:79-88.

36. Koning F, Gilissen L, Wymenga C. Gluten: a two-edge sword. Immunopathogenesis of celiac disease. Springer Semin Immun. 2005;27:217-22.

37. Kotze LMS, Paiva ADD, Kotze LR. Distúrbios emocionais em crianças e adolescentes portadores de doença celíaca. Rev Assoc Bras Med Psicossomática. 2000;4:9-15.

38. Kotze LMS, Utiyama SRR, Nisihara RM, Zeni MPB, Sena MG, Amarante HMS. Antiendomysium antibodies in Brazilian patients with celiac disease and their first-degree relatives. Arq Gastroenterol. 2001;36:94-103.

39. Kotze LMS, Utiyama SRR, Nisihara RM, de Camargo VF, Ioshii SO. IgA class antiendomysium and anti-transglutaminase antibodies in relation to duodenal mucosa changes in celiac disease. Pathology. 2003;35:56-60.

40. Kotze LMS. Gynecologic and obstetric findings related to nutritional status and adherence to a gluten-free diet in Brazilian patients with celiac disease. J Clin Gastroenterol. 2004;38:567-74.

41. Kotze LMS, Kotze LR Common variable immunodeficiency in Brazilian patient with celiac disease or celiac disease in patient with common variable immunodeficiency? [abstract]. (Presented at XII International Celiac Disease Symposium; 2006 November 9-11; New York, NY. Abstract D-333, p. 120).

42. Kotze LMS, Nisihara RM, Utiyama SRR, Piovesan GC, Kotze LR. Thyroid disorders in Brazilian patients with celiac disease. J Clin Gastroenterol 2006;40:33-6.

43. Kotze LMS, Nisihara RM, Utiyama SRR, Kotze LR. Celiac disease and hypothyroidism in an adult Brazilian female with Down syndrome. GED Gastroenterol Endosc Dig. 2007;26:55-8.

44. Leeds JS, Bunn RC, Sanders DS. Is there clinical relevance in testing patients with adult celiac disease for thyroid dysfunction? [abstract]. (Presented at XII International Celiac Disease Symposium; 2006 November 9-11; New York, NY. Abstract D-287, p.100).

45. Lewis HM, Reunala TL, Garioch JJ, Leonard JN, Fry JS, Collin P, Evans P, Fry L. Protective effect of gluten-free diet against development of lymphoma in dermatitis herpetiformis. Br J Dermatol. 1996;135:363-7.

46. Loftus CG, Loftus EV. Cancer risk in celiac disease. Gastroenterology. 2004; $123: 1726-9$

47. Logan RF, Rifkind EA, Turner ID, Ferguson A. Mortality in celiac disease Gastroenterology. 1989;97:265-71.

48. Ludolph T, Schweitzer A, Brenner A. Gastrointestinal tumors (GIST). Clinica characteristics, diagnosis, and therapy in five cases. Med Lin (Munich). 2006:101:6974.

49. Mearin ML, Catassi C, Brousse N, Brand R, Collin P, Fabiani E, Schweizer JJ, Abuzakouk M, Szajewska H, Halert C, Farre Masip C, Homes GK. European multi-centre study on coeliac disease and non-Hodgkin lymphoma. Eur J Gastroenterol Hepatol. 2006;18:187-94.

50. Meyer D, Stavropolous S, Diamond B, Shane E, Green PH. Osteoporosis in North American adult population with celiac disease. Am J Gastroenterol. 2001;96:112-9.

51. Moreno ML, Vasquez H, Mazure R, Smecuol E, Niveloni S, Pedreira S, Sugai E, Maurino E, Gómez JC, Bai JC. Stratifixation of bone fracture risk in patients with celiac disease. Clin Gastroenterol Hepatol. 2004;2:127-34.

52. Page SR, Lloyd CA, Hill PG, Peacock I, Holmes GK. The prevalence of coeliac disease in adult diabetes mellitus. Q J M. 1994;87:631-7.

53. Peters U, Askling J, Gridley G, Ekbom A, Linet M. Causes of death in patients with celiac disease in a population-based Swedish cohort. Arch Intern Med. 2003; 163:1566-72.

54. Reunala T, Collin P. Diseases associated with dermatitis herpetiformis. Br J Dermatol. 1996;136:315-8.

55. Rutz R, Ritzler E, Fierz W, Herzog D. Prevalence of asymptomatic celiac disease in adolescents of eastern Switzerland. Swiss Med Wkly. 2002;132:43-8.

56. Sanders DS, Hurlstone DP, McAlindon ME, Hadjivassiliou M, Cross SS, Wild G, Atkins CJ. Antibody negative coeliac disease presenting in elderly people - an easily missed diagnosis. BMJ. 2005;330:775-6.

57. Sategna-Guidetti C, Volta U, Ciacci C, Usai P, Carlino A, De Franceschi L, Camera A, Pelli A, Brossa C. Prevalence of thyroid disorders in untreated adult celiac disease patients and effect of gluten withdrawal: an Italian multicenter study. Am J Gastroenterol. 2001:96:751-7.

58. Sdepanian VL, de Miranda Carvalho CN, de Morais MB, Colugnati FA, FagundesNeto U. Bone mineral density of the lumbar spine in children and adolescents with celiac disease on a gluten-free diet in São Paulo, Brazil. J Pediatr Gastroenterol Nutr. 2003;37:571-6

59. Shanahan F, MsKenna R, McCarthy CF, Drury MI. Coeliac disease and diabetes mellitus: a study of 24 patients with HLA typing. Q J M. 1982;51:329-35.

60. Sjöberg K, Eriksson KF, Bredberg A, Wassmuth R, Eriksson S. Screening for coeliac disease in adult insulin-dependent diabetes mellitus. J Int Med. 1998:243:133-40. 
61. Strober W. Gluten sensitive-enteropathy. In: King R, Rotter JI, Motusky AG, editors. Genetic basis of common diseases. New York; Oxford University Press; 1992. p.279-304.

63. Swinson CM, Levi AJ. Is celiac disease underdiagnosed? Br Med J. 1980;281: 1258-60.

63. Swinson CM, Slavin G, Coles EC, Booth C. Coeliac disease and malignancy. Lancet. 1983;1:111-5.

64. Tanure MG, Silva IN, Bahia M, Penna FJ. Prevalence of celiac disease in Brazilian children with type 1 diabetes mellitus. J Pediatr Gastroenterol Nutr. 2006;42:155-9.

65. Tata LJ, Card TR, Logan RF, Hubbard RB, Smith CJ, West J. Fertility and pregnancy-related events in women with celiac disease: a population-based cohort study. Gastroenterology. 2005;128:849-55.

66. Tursi A, Brandimarte G, Giorgetti G. High prevalence of small intestinal bacteria overgrowth in celiac patients with persistence of gastrointestinal symptoms after gluten withdrawal. Am J Gastroenterol. 2003;98:839-43.

67. Utiyama SRR, Kotze LMS, Nisihara RM, Carvalho RF, de Carvalho EG, de Sena MG, de Messias-Reason IT. Spectrum of autoantibodies in celiac patients and relatives. Dig Dis Sci. 2001;46:2623-30.

68. Ventura A, Magazzu G, Greco L. Duration of exposure to gluten and risk for autoimmune disorders in patients with celiac disease. SIGEP Study Group for Autoimmune Disorders in Celiac Disease. Gastroenterology. 1999;117:297-303.

69. Verkasalo M, Tiilikainen A, Kuitunen P, Savilahti E, Backman A. HLA antigens and atopy in children with coeliac disease. Gut. 1983;24:306-10.
70. Volta U, Molinaro N, deFranceschi I, Fratangelo D, Bianchi FB. IgA antiendomysial antibodies on human umbilical cord tissue for celiac disease screening: save both money and monkeys. Dig Dis Sci. 1995;40:1902-5.

71. Volta U, Bardazzi F, Zauli D, deFranceschi L, Tosti A, Molinaro N, Ghetti S, Tetta C, Grassi A, Bianchi FB. Serological screening for coeliac disease in vitiligo and alopecia areata. Br J Dermatol 1997;136:801-2.

72. Wahab PJ, Meijer JW, Mulder CJ. Histologic follow-up of people with celiac disease on a gluten-free diet: slow and incomplete recovery. Am J Clin Pathol. 2002;118:459-63.

73. West J, Logan RF, Smith CJ, Hubbard RB, Card TR. Malignancy and mortality in people with celiac disease: population based cohort study. Br Med J 2004;329:716-9.

74. WGO-OMGE Practice Guideline. World Gastroenterology News. 2005;10(2 supplement):1-8.

75. Zauli D, Grassi A, Granito A, Foderaro S, De Franceschi L, Ballardini G, Bianchi FB, Volta U. Prevalence of silent coeliac disease in atopics. Dig Liver Dis. 2000;32:775-9

76. Zipser RD, Farid M, Baisch D, Patel B, Patel D. Physician awareness of celiac disease. J Gen Intern Med. 2005;20:644-6.

Recebido em 4/7/2008 Aprovado em 10/3/2009. 